\title{
Virus Detection and Production of Virus Free Plant Materials from the Lily by Selecting Basal Filament Flower as Explants
}

\author{
Yanjie Lv ${ }^{1}$, Yajun Dou ${ }^{1,2}$, Halizeremu Saidahemaiti ${ }^{1}$, Xiangfeng $\mathrm{He}^{1}$, \\ Xiangxun Zhao ${ }^{1}$ and Wenhe Wang ${ }^{1 *}$ \\ ${ }^{1}$ Beijing Agricultural College, Garden College 102206, China. \\ ${ }^{2}$ Majuqiao School of Tongzhou, District in Beijing, China.
}

Authors' contributions

This work was carried out in collaboration among all authors. All authors read and approved the final manuscript.

Article Information

DOI: $10.9734 / A R R B / 2021 / v 36 i 930429$ Editor(s):

(1) Prof. Ibrahim Farah, Jackson State University, USA. Reviewers:

(1) V. Venkataravanappa, ICAR-Indian Institute of Horticultural Research, India. (2) Geedhu Daniel, Nilgiri College of Arts and Science, India. Complete Peer review History: https://www.sdiarticle4.com/review-history/73845

Original Research Article

Received 07 July 2021

Accepted 17 September 2021 Published 01 October 2021

\begin{abstract}
Lilium is a perennial bulbous flower of Lily family Liliaceae, with high ornamental and economic value. However, Lily is vulnerable to virus infection, which seriously affects the yield and quality of Lily, and poses a great threat to the production, sales, especially export of Lily, and has caused huge economic losses to the related industries. Therefore, the research on lily virus removal methods and virus detection technology has important practical significance to improve the ornamental value and economic value of lily.

In this study, the filaments of four susceptible lily varieties,' Valdisole' (A),'Adoration'(LA),' Ice Cube'(OT) and 'Zantriana' $(\mathrm{O})$, were used as explants. The filaments of lily were divided into three parts, namely, top, middle, and base. In this paper, the virus detection of tissue culture seedlings induced by lily filaments was carried out by using DAS-ELISA and RT-PCR, and the removal effects of Cucumber mosaic virus, (CMV) and lily symptomless virus (LSV), two common viruses in lily, were explored, and the two detection technologies were compared.

The results showed that the success rate of tissue culture seedlings induced by filament base was the highest, and CMV virus could be basically removed. RT-PCR detection is more sensitive than
\end{abstract}


DAS-ELISA detection, but RT-PCR detection requires higher test conditions and technology. Therefore, appropriate virus detection methods can be selected according to actual conditions and severity.

Keywords: Lily filament; filaments culture; detoxification; virus detection.

\section{INTRODUCTION}

Lilium is a perennial bulbous flower of Liliaceae, which is one of the world's rare cut flowers with beautiful flower posture and colorful flowers. It is widely used in landscaping, food and medicine, and has high ornamental value and economic value. In production, lily mainly depends on conventional ball-splitting, ball-splitting bud scale cutting and scale embedding [1]. The advantages of adopting these methods are that they can keep the genetic basis of their offspring consistent and have less variation. However, these methods make the reproduction of lily small, especially after multiple generations of division, which often leads to species degeneration.

At present, many studies have successfully obtained regenerated plants by using different parts of lily, such as root, scales, stem tips, flowers, seeds, etc. [2-3] as explants, and established tissue culture technology of rapid asexual propagation system, which can quickly remove viral and renew varieties, accelerate the rapid propagation of lily and shorten the growth cycle of lily. However, the virus will be transmitted to the offspring through the vegetative body, which will gradually accumulate a large number of viral in the body and cause plant diseases. After several years of asexual reproduction of lily, viral damage will become more and more serious, resulting in variety degradation and serious virus disease [4]. The research shows that the incidence of lily vival disease is generally $40 \% \sim 50 \%$, and the virus-carrying rate of the second generation bulbs is over $90 \%$ [5]. After lily is infected with vival, its plants are infected for life and suffer for a long time, which leads to species degradation and destroys the normal physiological functions of the plants, and it is difficult to use chemical agents or biological agents for effective control, which seriously affects the yield and quality of fruits and the ornamental value of flowers and leaves [6]. Therefore, it is of great practical significance to explore the virus removal methods and virus detection techniques for improving the ornamental value and economic value of lily.
Because vival replication is closely related to plant metabolism, and some viruses have strong stress resistance, so far there is no effective control measure. Therefore, obtaining virus-free seedlings is the key to producing high-quality lily [7]. Phillips was the first to study the virus-free lily. After his successful virus-free lily shoot tip culture, many foreign scholars succeeded in using the shoot tip culture. In 1966, Mori and Hamaya obtained virus-free lily plants through the shoot tip culture [8]. At present, several countries in the world have successfully obtained virus-free lily vaccine by this method, which has been applied in production on a large scale. In addition, there are some new ways. Asano et al. used filaments of Lilium longiflorum for tissue culture, and obtained virus-free bulbs. Through in vitro culture technology, Israel has also successfully established a virus-free procedure for lily [9].

Bulbs are the most used explants in tissue culture of lily, which is also the most mature technology. However, because bulbs grow underground, carry more bacteria, have a high pollution rate, and are difficult to sterilize, and the sterilization process is relatively complex, it is difficult to ensure the quality of lily after planting for several years, and it is easy to be attacked by viruses and expand the harm range, so they are rarely used in the cultivation of virus-free seedlings. At present, detoxification is mainly carried out through the combination of shoot tip culture, bead bud culture, chemical method and heat treatment [10-12].

The theoretical basis of virus-free stem tip culture is that the virus is unevenly distributed in diseased plants, and the virus is contained in older organs and tissues [13-14]. The virus content is relatively low in young or immature tissues and organs such as stem tips, and the meristem of a part with active cell division such as stem tips has no vascular bundle, and the virus can only be transmitted through plasmodesmata, so it contains little or no virus. However, the problem that always puzzles researchers when using stem tip culture is: if the cut stem tip is too large and the survival rate is high, the detoxification effect is poor; If the cut stem tip is too small, the virus-free rate is high, 
but the operation is inconvenient and the survival rate is low. There are very few available stem tips on a lily bulb, which undoubtedly increases the cost of bulb source, and has high technical requirements, so it is difficult to popularize and produce on a large scale. Pearl bud culture is to peel off the external scales first, then disinfect the growing point of pearl bud with leaf primordium, rinse it with sterile water for several times, then peel off part of the Ye Yuan radical, and finally cut the growing point with 1-2 leaf primordium into small pieces with different lengths of $0.3-1.2 \mathrm{~mm}$ for culture under anatomical microscope to obtain virus-free seedlings [15-16]. However, for some viruses that are difficult to remove, it is difficult to achieve success by using this method alone. Chemical treatment is a new method of virus-free lily, which is to inject antiviral drugs into plants or add them into culture medium, so as to reduce the harm of virus [17]. However, it is difficult to completely remove the virus by using this method alone, so it needs to be combined with other methods. Heat treatment, also known as thermotherapy, is to treat plants at high temperature according to the difference of temperature sensitivity between plants and viruses, and to inactivate viruses at high temperature, so as to greatly reduce or stop their propagation speed in the host body. After being cultured at high temperature for several weeks to several months, the new plants, tissues or organs may grow without viruses [18], thus obtaining virus-free new plant tissues and propagating them to obtain virus-free seedlings [19]. In the heat treatment, the two most important factors are temperature and time. Most lily viruses have stable activity at $50 \sim 65^{\circ} \mathrm{C}$, so the virus can be inactivated at $65 \sim 75^{\circ} \mathrm{C}$. The longer the heat treatment time and the higher the temperature, the better the detoxification effect of lily, but the lower the survival rate of lily [20].

The differentiation rate of filament is obviously higher than that of other parts, and the time required for differentiation is shorter [21]. As an explant, the process of disinfection and induction culture is simple and easy to operate. After propagation, it can provide abundant experimental materials. At the same time, the growth speed of silk is fast, and there is little possibility of virus. On the whole, taking lily silk as test material is an ideal material for virus-free research, but there are few experiments on lily silk segmentation, so this experiment is innovative.

In this study, four susceptible lily varieties,' Val di sole',' Adoration',' Ice Cube' and' 'Zantriana"4, were used as experimental materials, and the non-toxic seed seedlings of Lilum pumilum DC. were used as blank control. By exploring the detoxification effects of different varieties and different filament parts, And compared the differences between two different virus detection technologies, summed up a set of perfect virusfree cultivation technology and rapid and accurate virus detection technology system, which provided scientific guidance for the nontoxic production of this lily variety.

\section{MATERIALS AND METHODS}

\subsection{Plant Materials}

The test materials of the lily varieties imported from Holland through SINO Floriculture Co, Ltd, which were planted continuously in the garden plant practice base of Beijing Agricultural College for 2 years, and their flower buds were taken for testing. The test materials were tested for CMV and LSV viruses RT-PCR using viral specific primers. Specific varieties, characteristics, and serial numbers are as follows.

Enzyme-linked immunosorbent assay kits for lily symptomless virus (LSV) and cucumber mosaic virus (CMV) are products of American ADGEN company, Trans Zol Plant RNA extraction kit (TransGen Biotech), RNase-free Water, isopropanol, chloroform, absolute ethanol and RT-PCR reverse transcription kit (TransGen Biotech).

\subsection{Materials Treatments}

Four diseased lily buds with consistent growth, immature and mature traits such as 'Val di Sole', 'Adoration', 'Icecube' , and 'Zantriana' were selected from the experimental base, and three buds were selected from each variety as three replicates. The cut buds were washed in running tap water for 30-60 min, and the surface water was sucked dry with filter paper before disinfection. On the ultra-clean bench, the buds were fully immersed in $75 \%$ alcohol solution for $10 \mathrm{~s}$, and then the alcohol on the buds was roasted with an alcohol lamp (about 40s). Selecting robust lily flower buds, nipping petals with tweezers, peeling filaments, cutting the peeled filaments into three sections, namely a base section, a middle section, and a top section, respectively. Inoculated on the medium of sucrose $50 \mathrm{~g} / \mathrm{L}$, agar $5 \mathrm{~g} / \mathrm{L}$, PH 6.0 , and recording the three sections with a marker pen; Each bottle was connected with 6 filament segments, and 9 bottles of one variety, totally 36 bottles. After 
inoculation, the formation of callus was observed, and the survival numbers of explants under each treatment were recorded. After about four weeks, statistical analysis was performed on the data, and the bulbar seedlings cultured after induction were proliferated. The presence virus in the tissue culture seedlings was confirmed the viruses (CMV and LSV) by DAS-ELISA and RT$\mathrm{PCR}$, and the virus-carrying status of the varieties was counted. In this study, the seedlings of Lilium pumilum DC. which were not infected with CMV and LSV viruses by RT-PCR were used as the blank control. The filaments were cultured at the temperature of $(24 \pm 2)^{\circ} \mathrm{Cand}$ the light intensity of $1500 \sim 2000$ lx (light time of 10-12 h/d) in the room.In this experiment, the optimum induction medium for 'Val di Sole' and 'adoration' varieties was obtained as follows: $\mathrm{MS}+\mathrm{BA} 1.0 \mathrm{mg} / \mathrm{l}+\mathrm{NAA} 0.5 \mathrm{mg} / \mathrm{l}+$ sugar $50 \mathrm{~g} / \mathrm{l}+$ agar $5 \mathrm{~g} / \mathrm{l}$; The most suitable induction medium for ' Ice Cube' and 'Zantriana' is MS+BA0.5mg/l+NAA0.5mg/l+ sugar $50 \mathrm{~g} / \mathrm{I}_{+}$ agar $5 \mathrm{~g} / \mathrm{l}$.The formula of propagation culture of four kinds of lily filaments is $\mathrm{MS}+\mathrm{BA} 0.2 \mathrm{mg} / \mathrm{l}+\mathrm{NAA} 0.05 \mathrm{mg} / \mathrm{l}+\mathrm{KT} 1 \mathrm{mg} / \mathrm{l}+$ sugar $60 \mathrm{~g} / \mathrm{l}+$ agar $6 \mathrm{~g} / \mathrm{l}$; All the media were autoclaved at $121^{\circ} \mathrm{C}$ for $18 \mathrm{~min}$, and then the filaments were inoculated. The culture temperature of filaments was controlled at about $25(2)^{\circ} \mathrm{C}$, and the illumination intensity was 1500 2000Lx, and the illumination time was $12 \mathrm{~h} / \mathrm{d}$.

\subsection{Determination of Lily Virus by DAS- ELISA}

Five offspring seedlings in tissue culture were randomly selected from each bud filament, with 15 plants in each variety and 60 samples in four varieties. An enzyme-linked immunosorbent assay (double antibody sandwich method) was used for confirm the viruses (CMV and LSV).

\subsection{RT-PCR Detection Technology of Lily Virus}

The five offspring seedlings (the same as the offspring seedlings in DAS-ELISA method) derived from floral filament expansion of each bud were randomly selected, totaling 15 plants per variety and 60 samples for four varieties.

1. Total RNA was extracted using TransZol PlantRNA extraction kit produced by TransGen Biotech was subjected PCR using specific primers for LSV and CMV

2. The primer sequences are shown in Table 2.

Table 1. The number and characteristics of the four kinds of lily

\begin{tabular}{llll}
\hline Coding No. & Part & Name & Bloom Color \\
\hline 1 & A & 'Val di Sole' & Yellow \\
2 & LA & 'Adoration' & White \\
3 & OT & 'Ice Cube' & White \\
4 & O & 'Zantriana' & Pink \\
\hline
\end{tabular}
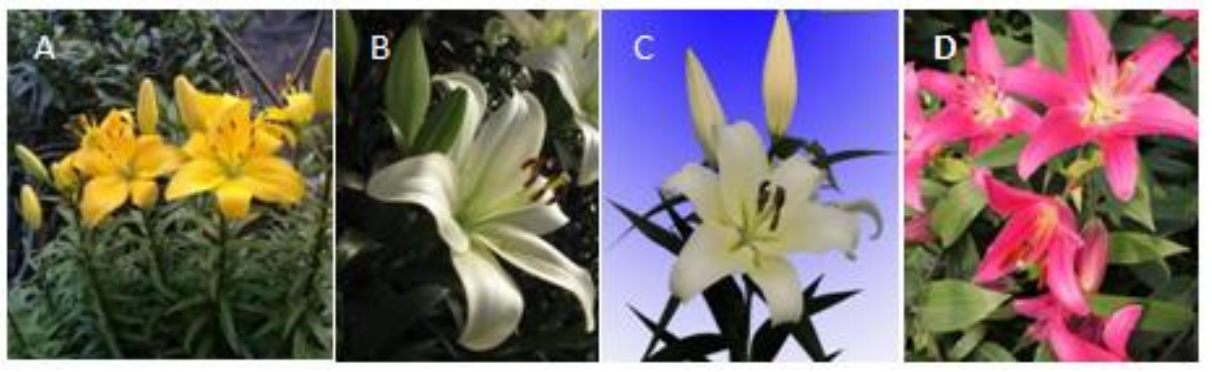

Fig. 1. A: A 'Val di Sole' B: LA 'Adoration' C: OT 'Ice Cube’ D: O‘ Zantriana'

Table 2. Primer sequences size and RT-PCR product size

\begin{tabular}{llll}
\hline Viruses & Upstream primer( 5'- 3') & Upstream primer( 5'- 3') & $\begin{array}{l}\text { Product size } \\
\text { ( bp })\end{array}$ \\
\hline LSV & GAAGAAGCACGCTGGACTG & CGCCTGATGATCCCCTC & 171 \\
CMV & ATGGACAAATCTGAATCAACCAG & TCAGACTGGGAGCACTCCAG & 657 \\
\hline
\end{tabular}


(3) The concentration of each primer in PCR, the denaturation, annealing ,and extension conditions of PCR as well as the cycle times were optimized to determine the optimal reaction mode. Reverse transcription at $42^{\circ} \mathrm{C}$ for $30 \mathrm{~min}$ and $94^{\circ} \mathrm{Cfor} 5 \mathrm{~min}$. The PCR reaction system was 20uL, including $2 \times$ One-Step Reaction Mix10ul, Easy script one-step enzyme mix 0.4ul, CMV and LSV upstream and downstream primers (10uM) $0.4 \mathrm{uL}, 0.4 \mathrm{ul}$ cDNA, RNase-free Water $8.4 \mathrm{uL}$. The optimized PCR program was as follows: predenaturation at $95^{\circ} \mathrm{C}$ for $4 \mathrm{~min}$, followed by denaturation at $95^{\circ} \mathrm{C}$ for $30 \mathrm{~s}$, annealing at $52^{\circ} \mathrm{C}$ for $30 \mathrm{~s}$, extension at $72{ }^{\circ} \mathrm{C}$ for $1 \mathrm{~min}, 35$ cycles, extension at $72{ }^{\circ} \mathrm{C}$ for $5 \mathrm{~min}$ and finally the reaction at $4^{\circ} \mathrm{C}$. Amplification was performed on

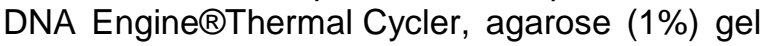
electrophoresis was performed, and the electrophoresis results were observed using a GelDoc1000 gel analyzer (Bio-Rad) and photographed. (5) Samples with sizes close to the target fragments amplified by PCR were sent to our company for sequencing, and the sequencing results were compared with relevant sequences in NCBI.

\section{RESULTS}

\subsection{The Induction Rate of the Base of the Filament was the Best}

The statistical analysis of the test data showed that the induction rates of the four lily varieties in different parts of the filament: (base > middle > top), the induction rate of the base of the filament was the best as compared to middle and top. Department of death, which is consistent with the research of Liu Limin et al.: Only the part near the base of the receptacle can induce bud or callus, and its other parts can't be inducedl[22].The induction rate of the base of the flower that 'Adoration', 'Zantriana' and 'Ice Cube' varieties was as high as $100 \%$, while that of the 'Val di Sole' variety was slightly lower, $61.1 \%$; The induction rate in the middle part of the filament of the cultivars of 'Adoration', 'Ice Cube', and 'Zantriana' was only $5.6 \%$, while that in the middle part of the filament of the cultivar of 'Val di Sole' was $0 \%$. No growth point was induced at the top of filament in four varieties. This results showed that different lily varieties had different induction effects on the filament. The induction rates of different filament parts in the same variety were also different. This may be due to the basal part of the filament had enough nutrients, and the tissue from the base to the top was tender and tender,it contains very small amount nutrients. In addition, it was related to the length of filament disinfection time. The longer the time was, the lower the survival rate of filament would be. The buds with different development degrees might also affect the test result. The specific reason remains to be further discussed.

\subsection{Detection of CMV and LSV Virus by DAS-ELISA in Lily}

It can be concluded from the table that the detoxification rate of 'Val di Sole' is $100 \%$; The virus-free rate of 'Adoration' was $93.3 \%$. The virus-free rate of ' Ice Cube' was $93.3 \%$. The virus-free rate of 'Zantriana' was $100 \%$. The experimental results showed that 'Val di Sole' and 'Zantriana' could completely remove CMV, while 'Adoration' and 'Ice Cube' could not completely remove CMV.

The detoxification rate of 'Val di Sole' was $26.7 \%$. The detoxification rate of 'Adoration' was 13.3\%; The detoxification rate of 'Ice Cube' was $20 \%$; The detoxification rate of 'Zantriana' was $26.7 \%$. The results showed that the four lilies could not completely remove LSV and the detoxification rate was low.

\subsection{The Detectable Rate of LSV was higher than that of CMV by DAS- ELISA Detection}

As can be seen intuitively from the table, samples harbored up to $78.33 \%$ LSV and a very low $3.33 \% \mathrm{CMV}$. It indicated that the removal rate of LSV from the four varieties of 'Val di Sole', 'Adoration', 'Ice Cube', and 'Zantriana' was very low, while the removal rate of CMV was very high or basically removed.

The results of this study showed that the detectable rate of LSV was higher than that of $\mathrm{CMV}$, and the detectable rate of CMV was extremely small, only $3.33 \%$, which might be related to the extent to which plant material was infected by virus and the characteristics of the virus itself. Liu Fen also pointed out in that the infection rate of LSV of Lilium davidii was greater than that of CMV [22], and LSV was difficult to remove from the Lilium davidii. From the detoxification effect of varieties, the detoxification effects of CMV and LSV from high to low were 'Zantriana', 'Val di Sole', 'Ice Cube', 'Adoration'; The detoxification effect of Lily 'Val di Sole' and 'Zantriana' varieties were better than that of 
'Adoration' and' Ice Cube' varieties. Plants having CMV infection was also infected with LSV. This result might be related to the characteristics of 'Adoration' and 'Ice Cube'. The of 'Adoration' and
'Ice Cube' was more robust than the 'Val di Sole' and 'Zantriana' in growth and not suitable for degradation. Once infected, the virus might also be difficult to remove.

Table 3. Lily filament number of flower buds, the inoculation site, the survival rate and thinduction rate

\begin{tabular}{|c|c|c|c|c|c|c|}
\hline $\begin{array}{l}\text { Lily } \\
\text { Varieties }\end{array}$ & $\begin{array}{l}\text { Serial } \\
\text { number }\end{array}$ & $\begin{array}{l}\text { Bud } \\
\text { Number } \\
\text { (piece) }\end{array}$ & $\begin{array}{l}\text { Vaccination } \\
\text { site }\end{array}$ & $\begin{array}{l}\text { Inoculated } \\
\text { filaments } \\
\text { number(piece) }\end{array}$ & $\begin{array}{l}\text { Survival } \\
\text { number(piece) }\end{array}$ & $\begin{array}{l}\text { Survival } \\
\text { Rate (\%) }\end{array}$ \\
\hline Val di & 1 & & Top & 18 & 0 & 0 \\
\hline \multirow[t]{2}{*}{ Sole' } & & 3 & middle & 18 & 0 & 0 \\
\hline & & & base & 18 & 11 & 61.1 \\
\hline \multirow[t]{3}{*}{ 'Adoration' } & 2 & & top & 18 & 0 & 0 \\
\hline & & 3 & middle & 18 & 1 & 5.6 \\
\hline & & & base & 18 & 18 & 100 \\
\hline \multirow[t]{2}{*}{ 'Ice Cube' } & 3 & & top & 18 & 0 & 0 \\
\hline & & 3 & $\begin{array}{l}\text { middle } \\
\text { base }\end{array}$ & $\begin{array}{l}18 \\
18\end{array}$ & $\begin{array}{l}1 \\
18\end{array}$ & $\begin{array}{l}5.6 \\
100\end{array}$ \\
\hline \multirow[t]{3}{*}{ 'Zantriana' } & 4 & & & 18 & 0 & 0 \\
\hline & & 3 & middle & 18 & 1 & 5.6 \\
\hline & & & base & 18 & 18 & 100 \\
\hline
\end{tabular}

Table 4. The value of CMV detected by OD

\begin{tabular}{lllllllllllll}
\hline OD & $\mathbf{1}$ & $\mathbf{2}$ & $\mathbf{3}$ & $\mathbf{4}$ & $\mathbf{5}$ & $\mathbf{6}$ & $\mathbf{7}$ & $\mathbf{8}$ & $\mathbf{9}$ & $\mathbf{1 0}$ & $\mathbf{1 1}$ & $\mathbf{1 2}$ \\
\hline $\mathrm{A}$ & 1.196 & 0.108 & 0.100 & 0.101 & 0.103 & 0.105 & 0.093 & 0.096 & 0.082 & 0.001 & 0.002 & 0.001 \\
$\mathrm{~B}$ & 1.205 & 0.099 & 0.106 & 0.094 & 0.122 & 0.118 & 0.104 & 0.116 & 0.151 & 0.001 & 0.001 & 0.002 \\
$\mathrm{C}$ & 1.202 & 0.099 & 0.108 & 0.105 & 0.281 & 0.112 & 0.117 & 0.105 & 0.159 & 0.001 & 0.001 & 0.001 \\
$\mathrm{D}$ & 0.082 & 0.117 & 0.091 & 0.108 & 0.102 & 0.114 & 0.111 & 0.115 & 0.136 & 0.001 & 0.002 & 0.001 \\
$\mathrm{E}$ & 0.088 & 0.104 & 0.099 & 0.285 & 0.129 & 0.133 & 0.103 & 0.099 & 0.125 & 0.002 & 0.001 & 0.001 \\
$\mathrm{~F}$ & 0.182 & 0.100 & 0.101 & 0.098 & 0.108 & 0.120 & 0.115 & 0.109 & 0.119 & 0.001 & 0.002 & 0.002 \\
$\mathrm{G}$ & 0.221 & 0.106 & 0.104 & 0.111 & 0.116 & 0.114 & 0.102 & 0.126 & 0.167 & 0.001 & 0.002 & 0.001 \\
$\mathrm{H}$ & 0.188 & 0.081 & 0.094 & 0.096 & 0.110 & 0.002 & 0.001 & 0.001 & 0.002 & 0.002 & 0.001 & 0.002 \\
\hline \multicolumn{7}{c}{ Note: Well A1-C1 is the positive control, Well F1-H1 is the negative control, Well D1-E1 is the blank value, well } \\
A2-A9 and B2-B8 were 'Val di Sole', well B9, C2-C9, and D2-D7 were 'Adoration' well D8-D9, E2-E9 and F2-F6 \\
were 'Ice Cube', well F7-F9, G2-G9, and H2-H5 were 'Zantriana'. The OD value of each sample was detected by \\
ELISA reader, and the average OD value of the positive control was calculated to be 1.201. The mean OD value \\
of that negative control was O.197; The blank mean OD value was 0.085.
\end{tabular}

Table 5. The value of LSV detected by OD

\begin{tabular}{lllllllllllll}
\hline OD & $\mathbf{1}$ & $\mathbf{2}$ & $\mathbf{3}$ & $\mathbf{4}$ & $\mathbf{5}$ & $\mathbf{6}$ & $\mathbf{7}$ & $\mathbf{8}$ & $\mathbf{9}$ & $\mathbf{1 0}$ & $\mathbf{1 1}$ & $\mathbf{1 2}$ \\
\hline $\mathrm{A}$ & 0.747 & 0.079 & 0.093 & 0.098 & 0.082 & 0.163 & 0.083 & 0.101 & 0.230 & 0.001 & 0.000 & 0.001 \\
$\mathrm{~B}$ & 0.715 & 0.102 & 0.099 & 0.085 & 0.090 & 0.088 & 0.103 & 0.090 & 0.165 & 0.001 & 0.001 & 0.002 \\
$\mathrm{C}$ & 0.726 & 0.089 & 0.088 & 0.094 & 0.104 & 0.127 & 0.101 & 0.098 & 0.138 & 0.001 & 0.001 & 0.001 \\
$\mathrm{D}$ & 0.062 & 0.085 & 0.130 & 0.093 & 0.186 & 0.109 & 0.078 & 0.136 & 0.093 & 0.001 & 0.000 & 0.001 \\
$\mathrm{E}$ & 0.052 & 0.086 & 0.085 & 0.095 & 0.094 & 0.086 & 0.163 & 0.107 & 0.143 & 0.000 & 0.001 & 0.001 \\
$\mathrm{~F}$ & 0.099 & 0.088 & 0.156 & 0.099 & 0.097 & 0.099 & 0.102 & 0.111 & 0.119 & 0.001 & 0.000 & 0.000 \\
G & 0.085 & 0.089 & 0.094 & 0.082 & 0.099 & 0.084 & 0.096 & 0.096 & 0.170 & 0.001 & 0.000 & 0.001 \\
H & 0.076 & 0.069 & 0.073 & 0.100 & 0.092 & 0.000 & 0.001 & 0.001 & 0.000 & 0.000 & 0.001 & 0.000 \\
\hline
\end{tabular}

Note: Well A1-C1 was the positive control, Well F1-H1was the negative control, Well D1-E1 was the blank value, well A2-A9 and B2-B8 were 'Val di Sole', well B9,C2-C9, and D2-D7 were 'Adoration' well D8-D9, E2-E9 and F2-

F6 were 'Ice Cube', well F7-F9,G2-G9, and H2-H5 were 'Zantriana'. The OD value of each sample was detected by ELISA reader, and the average OD value of the positive control was calculated to be 0.729 . The mean OD value of that negative control was 0.087 ; The blank average $O D$ value was 0.057 , and the relevant data statistics were shown in Table 5 
Table 6. The statistics of DAS-ELISA detection

\begin{tabular}{lllllll}
\hline $\begin{array}{l}\text { Variety } \\
\text { Name }\end{array}$ & $\begin{array}{l}\text { CMV } \\
\text { Virus-free } \\
\text { rate(\%) }\end{array}$ & $\begin{array}{l}\text { The quantity } \\
\text { detection } \\
\text { (piece) }\end{array}$ & $\begin{array}{l}\text { Average } \\
\text { relevance } \\
\text { ration(\%) }\end{array}$ & $\begin{array}{l}\text { LSV Virus- } \\
\text { free } \\
\text { rate(\%) }\end{array}$ & $\begin{array}{l}\text { The quantity } \\
\text { detection } \\
\text { ( piece) }\end{array}$ & $\begin{array}{l}\text { Average } \\
\text { relevance } \\
\text { ration(\%) }\end{array}$ \\
\hline 'Val di Sole' & 100.0 & 0 & & 26.67 & 11 & \\
'Adoration' & 93.33 & 1 & 3.33 & 13.33 & 13 & 78.33 \\
'Ice Cube', & 93.33 & 1 & & 20.0 & 12 & \\
'Zantriana' & 100.0 & 0 & & 26.67 & 11 & \\
\hline
\end{tabular}

\subsection{Detection of CMV and LSV in Lily by RT-PCR}

Test results of CMV: A (about 657bp) and LSV: B (about 171bp) of 'val di Sole'

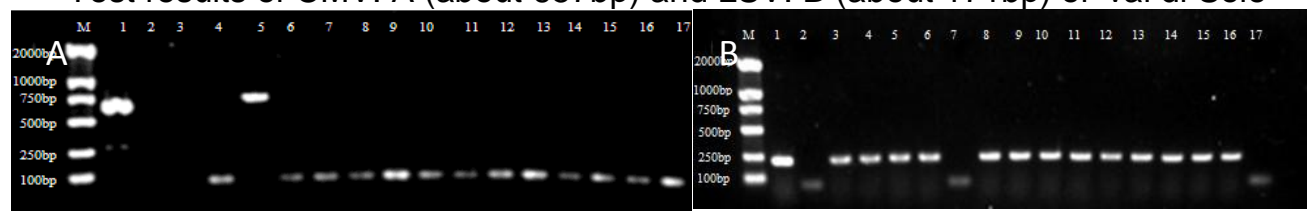

Worship the results of the 'Adoration' cultivars CMV: C (approximately 657bp) and LSV:D (approximately 171bp)

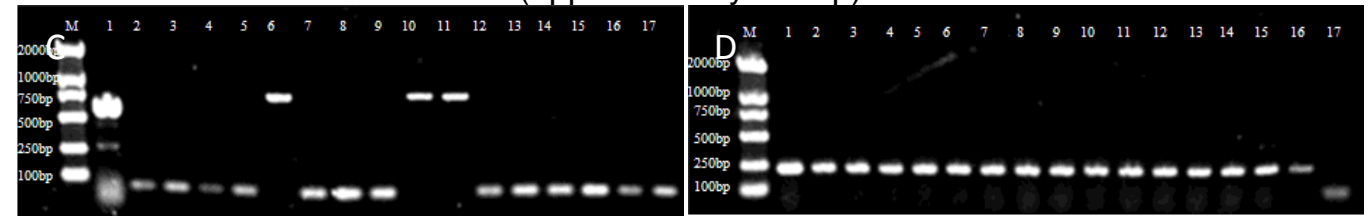

Test Results for CMV:E (approximately 657bp) and LSV:F (approximately 171bp) ' Icecube'.

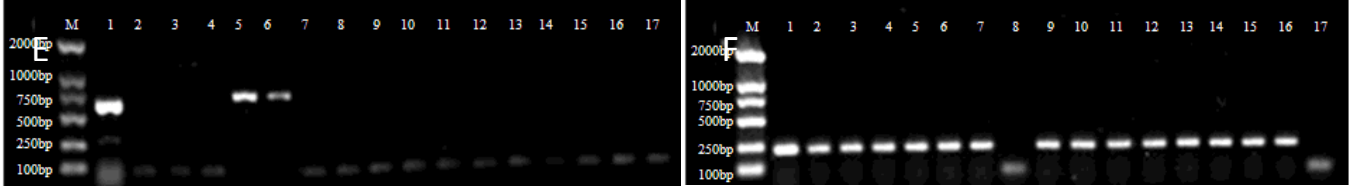

Results of CMV:G (about 657bp) and LSV:H (about 171bp) Test for 'Zantriana'.
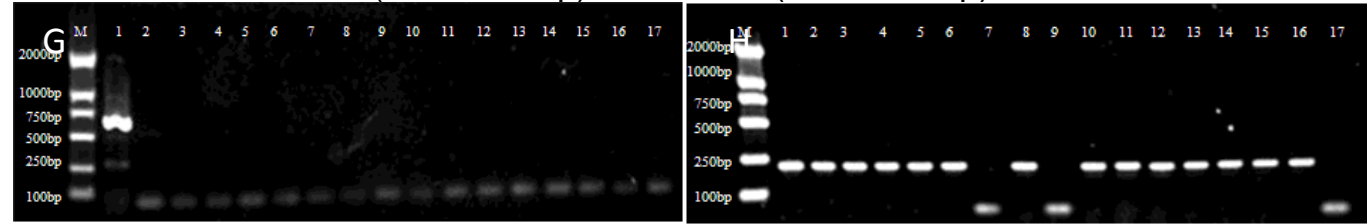

Fig. 2. Well 1 was the original plant, and the LSV virus band was clear and bright. Well 2-16 were the filament tissue culture seedlings of three buds of this variety, 15 plants in total, and Well 17 was the blank control

\subsubsection{The detoxification rate of CMV and LSV in lily by RT-PCR virus detection}

A PCR assay was performed on 15 samples from each lily variety of 'Val di Sole', 'Adoration', 'Ice Cube', and 'Zantriana'. The detoxification rates of CMV and LSV were counted as follows:

As shown in Table 6, the virus-free rates of CMV virus on the base of flower filament of ' $\mathrm{Val} \mathrm{di}$ Sole', 'Adoration', 'Ice Cube' and 'Zantriana' were $93.3 \%, 80.0 \%, 86.7 \%$, and $100.0 \%$, respectively. The detoxification rates of LSV were $13.3 \%$, $0.0 \%, 6.7 \%$ and $13.3 \%$, respectively. It was obvious that the detoxification rate of CMV was higher than that of LSV. From the detoxification effect of varieties, the detoxification effects of CMV and LSV were 'Zantriana', ' Val di Sole', 'Ice Cube', 'Adoration' from high to low; The detoxification effect of 'Val di Sole' and 'Zantriana' varieties was better than that of 'Adoration' and 'Ice Cube' varieties. Plants with CMV also carry LSV.

\section{DISCUSSION}

The experiment by Yao et al. showed that the differentiation rate of filament was significantly 
Table 7. The statistics of RT-PCR detection

\begin{tabular}{llll}
\hline Serial number & Variety Name & CMV Virus-free Rate (\%) & LSV Virus-free Rate (\%) \\
\hline $1(\mathrm{~A})$ & 'Val di Sole' & 93.3 & 13.3 \\
$2(\mathrm{LA})$ & 'Adoration' & 80.0 & 0.0 \\
$3(\mathrm{OT})$ & 'Ice Cube' & 86.7 & 6.7 \\
$4(\mathrm{O})$ & 'Zantriana' & 100.0 & 13.3 \\
\hline
\end{tabular}

higher than that in other parts and the differentiation required a shorter time [21]. In this study, the color of the silk gradually changed from pale yellow or white to green, with both ends of the incision tilted, 5-7 d after inoculation. After about $20 \mathrm{~d}$, the incision site was obviously enlarged, indicating that callus had been produced in the tissue. After 25-30 d of culture, an exophytic callus was formed around the incision at the lower end of the explant. The protuberant callus varied in size, and the surface was uneven. About $40 \mathrm{~d}$ to $45 \mathrm{~d}$, bud differentiation appeared on the callus, and then the filaments were further elongated and thickened, and the base was further expanded. The buds came together to form a bud cluster and gradually extended out of the green leaves from about $56 \mathrm{~d}$ to $60 \mathrm{~d}$. In this process, the top and middle parts were almost free from swelling. The above test results are similar to the studies by others.

\section{CONCLUSION}

In this study, the filaments of four susceptible lilies,' Val di Sole' (A),' Adoption' (LA),' Ice Cube' (OT) and' zantriana' (O), were used as explants, and the filaments of lilies were divided into three parts: top, middle and base, which were induced and cultured to form callus respectively, and tissue culture seedlings were produced. To explore the virus-free effects of different varieties and different lily filament parts, and to compare the differences between two different virus detection techniques. According to the test results, the following main conclusions are drawn:

The experiment showed that the base (lower end of morphology) of filament was easy to grow growth points, and the induction rate was higher, while the induction rate in the middle was lower, while all the filaments died at the top. This result is probably due to the abundant nutrients at the base of filament, while the tender tissue at the top is low in nutrients.

The four lily filaments were used as explants for tissue culture, and the optimum induction medium for' Val di Sole' and' adoption' was
$\mathrm{MS}+\mathrm{BA} 1.0 \mathrm{mg} / \mathrm{l}+\mathrm{NAA} 0.5 \mathrm{mg} / \mathrm{l}+$ sugar $50 \mathrm{~g} / \mathrm{l}+$ agar $5 \mathrm{~g} / \mathrm{l}$; The most suitable induction medium for 'Ice Cube' and 'Zantriana' varieties is MS+BA0.5mg/l+NAA0.5mg/l+ sugar $50 \mathrm{~g} / \mathrm{l}+$ agar $5 \mathrm{~g} / \mathrm{l}$.. Different varieties of lily filaments have different optimal induction media, which may be related to the genotype and physiological characteristics of the varieties.

In this experiment, DAS-ELISA and RT-PCR were used to detect the virus-free rates of CMV and LSV at the flower base of' Val di Sole','Adoption',' ice cube' and' Zantriana'. from the point of view of virus-free effect, the virusfree effect of lily flower base on CMV is similar to that of stem tip, but the virus-free effect on LSV is poor, which may be similar to that of lily itself. The virus-free effect of lily varieties' Val di Sole' and' Zantriana' is better than that of the white romantic' Ice Cube' which worships' Adoration'. This result may be due to the fact that' Adoration' and' Ice Cube' are stronger in cultivation than those of' Val di Sole' and' Zantriana', which are not suitable for degradation and may be difficult to remove once infected with viruses. Whether there is any difference in virus removal difficulty among different hybrid lines of lilies needs further study.

Comparing the values of the two detection methods, it is found that RT-PCR is more accurate than DAS-ELISA, It shows that RT-PCR detection technology has higher sensitivity and stronger specificity, but it has strict requirements on experimental operation technology. And DASELISA is simpler and faster to operate, without special instruments and equipment, and the results are easier to judge. Although the sensitivity is not high enough and the virus kit is expensive, it can be applied to general production practice. To sum up, appropriate virus detection methods can be selected according to actual conditions and severity.

\section{DISCLAIMER}

The products used for this research are commonly and predominantly use products in our area of research and country. There is absolutely 
no conflict of interest between the authors and producers of the products because we do not intend to use these products as an avenue for any litigation but for the advancement of knowledge. Also, the research was not funded by the producing company rather it was funded by personal efforts of the authors.

\section{ACKNOWLEDGEMENTS}

First of all, I sincerely thank my tutor Professor Wang Wenhe. I finished this project under the care of my tutor Wang Wenhe. During the whole experiment, I would like to thank Professor Zhao Xiangyun for his selfless guidance and help. In addition, I would like to thank Mr. He Xiangfeng for his great guidance and help in virus detection technology. Thank you for the support of scientific research projects: Research and training program for college students in Beijing Agricultural College; Science and Technology Promotion Project of Beijing Municipal Education Commission (PXM2013-014207-000079; PXM2014-014207-000081;PXM2014-014207000018);;Innovative team building and teacher career development plan project in Beijing universities (IDHT20150503). Project of Beijing Municipal Bureau of Landscaping and Greening (YLHH201300102; YLHH201400102).

\section{COMPETING INTERESTS}

Authors have declared that no competing interests exist.

\section{REFERENCES}

1. Jiang Xiwang, Si Huaijun. Summary of lily tissue culture technology [J]. Hubei Agricultural Sciences, 2004;01:78 82.

2. Liu Fen, Wang Falin. Study on virus-free technology of Lanzhou lily [J]. Henan Agricultural Sciences. 2007,(07): 93 95.

3. Zhao Deping, Tang Daocheng, Liu Mihui, et al. Study on organ tissue culture of oriental lily [J]. Northern Horticultural Science, 2008(2) :198 200.

4. Wang Yongwei, Wang Huixia, He Dan, et al. Research status and development trend of virus diseases and virus removal in ornamental plants [J]. chinese agricultural science bulletin. 2008(24):313 317.

5. Wang Jihua, Tang Kai-Xue, Zhang Zhongkai, et al. Progress in detection of lily virus and its detoxification [J]. Northern Horticultural Science. 2004,(6):73-75.
6. Wang Lihua, Wang Jihua, Qu Suping, et al. Research progress on virus-free and detection technology of lily [J]. Guangxi Agricultural Sciences. 2007;38(06): 673 677.

7. Zheng Lina. Study on detection and removal technology of lily bulb virus [D]. Beijing: Beijing Forestry University;2009.

8. Cao Ziyi, Liu Guoming. Practical Course of Plant Tissue Culture Technology [M]. Gansu: Gansu Science and Technology Press; 1996.

9. Liang Qiaolan. Study on the pathogenic factors and virus detection methods of lily virus disease [M]. Gansu Agricultural University;2004.

10. Wang Jihua, Tang Kai-Xue, Zhang Zhongkai, et al. Progress in detection of lily virus and its detoxification [J]. Northern Horticultural Science. 2004,(6):73 75.

11. Liu Yanni, She Kuijun. Research progress of lily virus-free technology [J]. Ningxia Agriculture and Forestry Science and Technology. 2014,55(08):10 11,15.

12. Shao Zenglong, Gao Shanlin, Huang Heping, et al. Study on virus-free and rapid propagation technology of lily [J]. pharmaceutical biotechnology. 2010,17(3): 240 243.

13. Zhu Xudong, Tian Songqing, Cheng Haizhong, et al. Study on tissue culture technology of oriental lily stem tip [J]. Anhui Agricultural Sciences.2009,37 (5):1922-1962.

14. Jin Huijie. Detection of Oriental Lily virus and research on ultra-low temperature virus removal from stem tips [D]. Fuzhou: Fujian Agriculture and Forestry University; 2009.

15. Zhao Xiangyun, Cheng Lian, Xing Youmei, et al. Study on tissue culture and virus-free of lily beads [J]. Acta Horticultural Sinica. 1993;20(3):284 288

16. Leng Xiao Xun, Wang Qinghua. Tissue Culture of Lily [J]. Northern Horticultural Science. 1999;6:59.

17. Li Shirun, Huang Yue. Research progress on detoxification of horticultural plants [J]. Research on Agriculture and Animal Husbandry Information. 1992;2:36 40.

18. Cao Ziyi, Liu Guoming. Practical Course of Plant Tissue Culture Technology [M]. Gansu: Gansu Science and Technology Press;1996.

19. Gibbs J. Essentials of Plant Virology [M]. Shanghai: Shanghai Science Press. 1982;87. 
20. Zhang Huihua, Liu Xiaorong, Yan Fanyue, et al. Study on comprehensive detoxification technology of oriental lily [J]. Liaoning Agricultural Sciences. 2009; (6):17 19.

21. Yao Shao-Chang, Yang Mei-chun, Ling Zheng-Zhu. Study on the regeneration of
Asian lily by organ tissue culture [J]. Anhui Agricultural Sciences. 2010,38(7): 3459 3460.

22. Xu rongxue, Ming jun, mu ding, et al. multiplex RT-PCR detection of three lily viruses $[\mathrm{J}]$. acta horticulture sinica, 2007,34(2):443-448.

(C) 2021 Yanjie et al.; This is an Open Access article distributed under the terms of the Creative Commons Attribution License (http://creativecommons.org/licenses/by/4.0), which permits unrestricted use, distribution, and reproduction in any medium, provided the original work is properly cited.

Peer-review history:

The peer review history for this paper can be accessed here:

https://www.sdiarticle4.com/review-history/73845 